\title{
Analyse ved røntgendiffraktion - Rietveld-metoden
}

Af Svend Erik Rasmussen, Geologisk Institut, Aarhus Universitet.

Skarpe veldefinerede røntgenreflekser kan opnås ved at sende monokromatisk røntgenstråling ind mod en pulverformig krystallinsk prøve. Ud fra kendskab til krystalstrukturer med mere kan pulverdiffraktogrammer beregnes for såvel rene faser som for blandinger. Ud fra observerede data kan man ved sammenligning med beregnede værdier opnå kvantitative modalanalyser ved en metode kaldet Rietveld-metoden.

I 1912 fandt M. von Laue sammen med P. Knipping og W. L. Friedrich, at røntgenstråling spredes fra krystaller efter et interferensprincip, således at spredningen er begrænset til bestemte vinkler. Heraf kunne der drages to konklusioner:

1. Røntgenstråling måtte opfattes som en bølgebevægelse.

2. Krystallers atomer er arrangeret systematisk, som i et gitter.

Figuren øverst på denne side viser deres opstilling, hvor røntgenstrålen passerer gennem krystallen.

W. L. Bragg viste i 1913, at spredningen af røntgenstråling kunne opfattes som en refleksion af strålingen fra planer gennem krystallen, som antydet i mellemste figur, og at betingelsen for refleksion kunne udtrykkes ved ligningen: $\lambda=2 \mathrm{~d} \sin \theta$, hvor $\lambda$ er strålingens bølgelængde, $\theta$ er refleksionsvinklen og d afstanden mellem de reflekterende planer.

Ligningen, som kaldes Braggs lov, har vist sig at være særdeles nyttig og betydningsfuld. En meget forenklet tegning, figuren nederst til højre, viser princippet for et instrument, der bygger på anvendelsen af ovenstående formel.

\section{De første eksperimenter}

De første eksperimenter med røntgendiffraktion blev udført med ret store énkrystaller. I 1916 viste Debye og Scherrer imidlertid, at skarpe veldefinerede røntgenreflekser kunne opnås ved at sende monokromatisk røntgenstråling ind mod en pulverformig krystallinsk prøve. De påviste, at linjerne

Princippet for Laue, Friedrich, Knipping eksperimentet. Et sncevert bundt af polykromatisk røntgenstråling sendes gennem krystallen, og spredningen af strålingen registreres på en film, hvis plan er vinkelret på røntgenstrålen. (Grafik: UVH modificeret efter Bijvoet, $J$. M.,Kolkmeyer N. H. \& MacGillavry, C. H. (1951) XRay Analysis of Crystals)

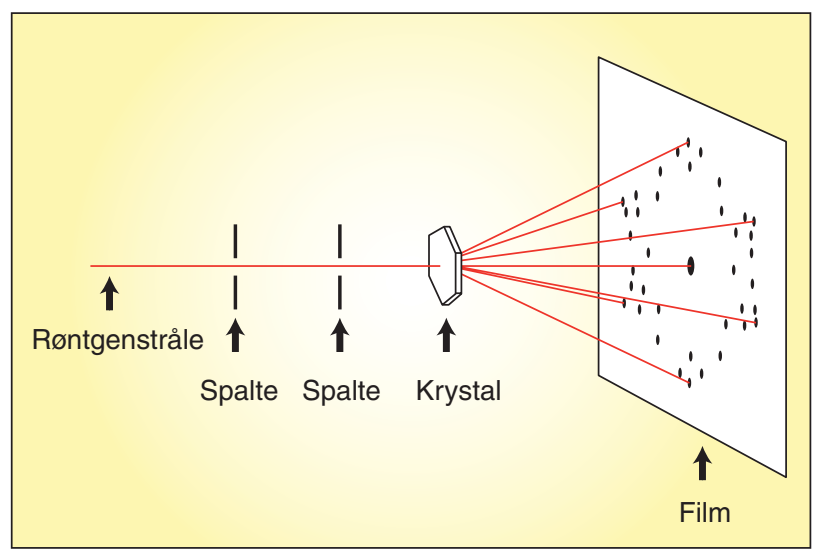

Vinklen for den indfaldne stråling med bølgeloengde $\lambda$ er $\theta$, der er lig refleksionsvinklen. Afstanden mellem de reflekterende planer er d. Forskellen i vejlaengde mellem den indfaldne og den reflekterede stråling er $A B$ $+B C \operatorname{og} A B=B C$. Figuren viser, at $A B=d \sin \theta$, og forskellen $i$ vejlaengde er da $A B$ $+B C=2 d \sin \theta$. Hvis to suc-

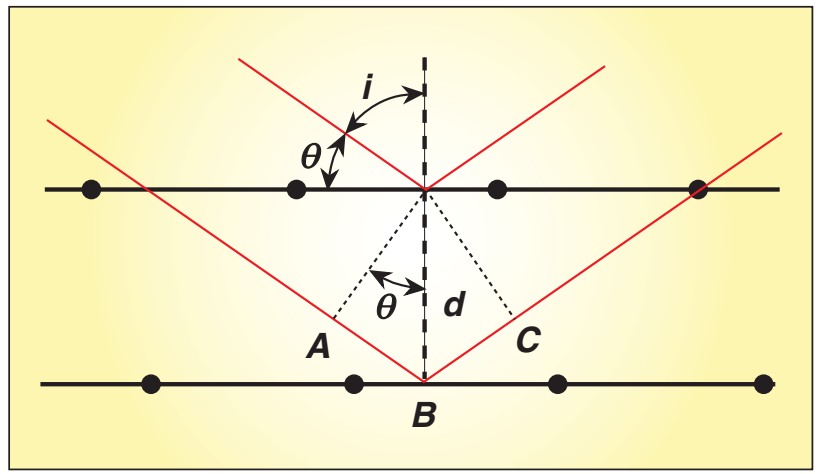
cessive bølgetog skal forstcerke hinanden, skal vejforskellen vore et helt antal bølgelcengder, hvilket udtrykkes ved ligningen: $n \lambda=2 d \sin \theta$. (Grafik: UVH modificeret efter forlaeg af uvis oprindelse)

Ved hjoelp af spalten $S_{1}$ udvaelges et sncevert strålebundt, der rammer krystallen under vinklen $\theta$. Stråling spredes fra krystallen $i$ alle retninger, men kun den del, der reflekteres med vinklen $\theta$, vil kunne komme ind i detektoren gennem spalten $S_{2}$. Krystal og detektor kan dreje om en fcelles akse, således at indfaldsvinkel og refleksi-

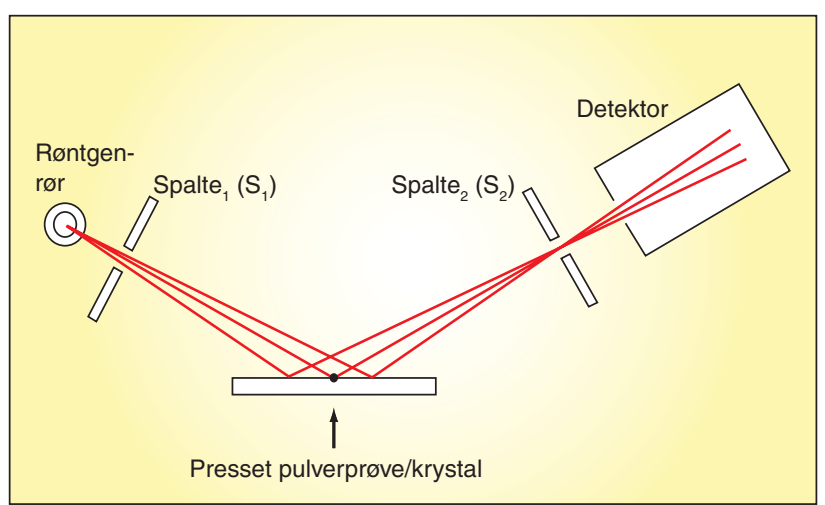

onsvinkel er ens. Det viste sig senere, at en presset pulverprøve anbragt på krystallens plads kunne reflektere røntgenstråling. (Grafik: UVH modificeret efter forlag af uvis oprindelse)

fremkom som resultat af, at der blandt de mange små krystalkorn altid var nogle, der lå på en sådan måde, at Braggs lov var opfyldt for de planer, man kan lægge igennem krystalgitret. De konkluderede også, at man ved deres metode kunne skelne mellem mikrokrystallinske og egentligt amorfe stoffer. Fotoet øverst på næste side viser et pulverdiagram af silicium optaget ved hjælp af Debye-Scherrer-teknikken. 
Den spredte røntgenstråling er her registreret på film. Filmregistrering anvendes nu praktisk taget ikke mere til røntgendiffraktion. (Foto: Forfatteren)

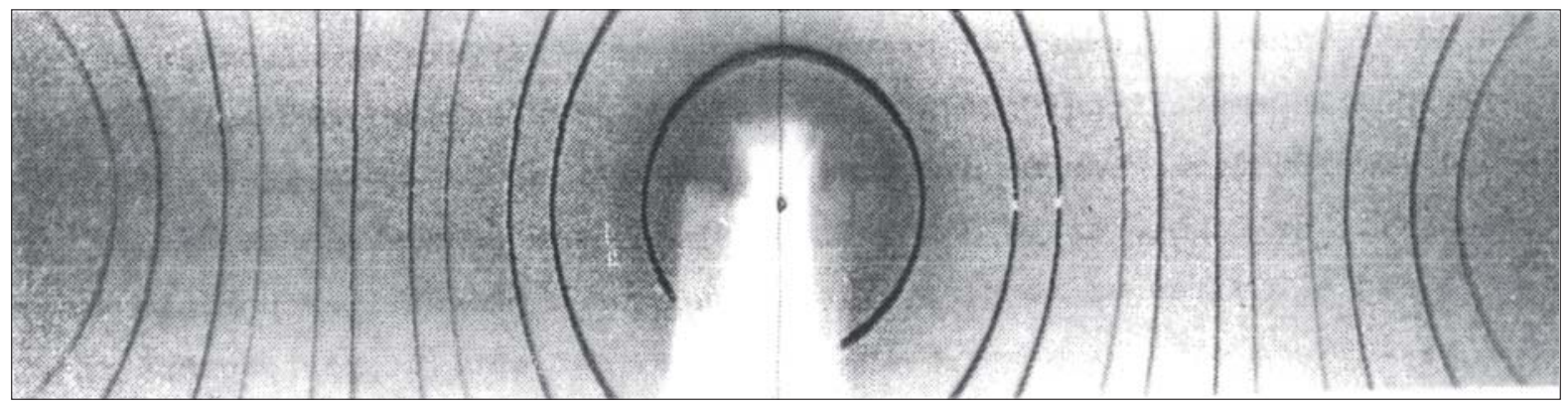

Debye og Scherrer benyttede en transmissionsteknik, hvor røntgenstrålingen sendes igennem en cylindrisk prøve. Man fand imidlertid hurtigt ud af, at man også kunne bruge den af Bragg udviklede metode på pressede pulverprøver, som antydet i figuren nederst på foregående side. Instrumenter baseret på den grundmetode er i dag måske de mest udbredte til pulverdiffraktion. Et pulverdiagram optaget med et moderne diffraktometer er vist i figuren nedenfor.

\section{Kvalitativ faseanalyse}

Røntgenpulverdiffraktion blev i de første år efter metodens fremkomst hovedsageligt brugt til analyse af simple krystalstrukturer, men fik senere den største udbredelse som analytisk hjælpeværktøj i kemi og mineralogi.

Der er i USA i årenes løb blevet opbygget en database kaldet Powder Diffraction File, PDF, med standardiserede oplysninger om pulverdiagrammer fra ca. 190.000 forbindelser. Når der er flere faser tilstede i en pulverprøve, giver hver fase sit diagram uafhængigt af tilstedeværelsen af andre faser. Det er baggrunden for, at man siger, at et stofs pulverdiagram kan opfattes som stoffets "fingeraftryk". Figuren øverst på næste side viser et eksempel på diffraktogrammer af henholdsvis rent kvarts, ren calcit og en blanding af kvarts og calcit.

\section{Kvantitativ faseanalyse}

Identifikation af et rent stof, der er registreret $\mathrm{i}$ ovennævnte database, er i dag en rutineopgave, men ofte står kemikere og især geologer over for den opgave at analysere flerfasesystemer, og også gerne at kunne give en kvantitativ analyse af faserne. Mineraloger har i mange år med held anvendt polarisationsmikroskopet til identifikation af mineraler og også til kvantitative evalueringer, men også her har røntgendiffraktion bidraget til øget sikkerhed i analysen. Den teknologiske udvikling har ført til, at det er muligt at anvende både store datamængder og raffinerede programsystemer på relativt billige personlige computere. Som regel er anskaffelse af database og tilhørende programmel en større udgift end købet af en computer.

Ved den kvantitative analyse af flerfasesystemer kan man ikke direkte anvende intensiteter af udvalgte diffraktionslinjer fra de enkelte komponenter til en kvantitativ analyse. Man er her henvist til sammenligning med kendte standarder for at opnå pålidelige resultater. Der er forskellige metoder til brug af standarder, men de vil ikke blive nærmere omtalt her, da formålet er, at beskrive en standardfri metode.

Bestemmelsen af en kemisk forbindelses struktur ud fra røntgenkrystallografiske målinger er ikke en rutineopgave, men et pulverdiffraktogram kan helt entydigt beregnes ud fra en kendt struktur. For et flerfasesytem, hvor strukturerne af de enkelte faser er kendte, kan man beregne diffraktogrammet for systemet som helhed, og bestemme de relative mængder af de indgående forbindelser ved at tilpasse observerede intensiteter med beregnede ved iterative metoder. En udbredt metode kaldes Rietveld-metoden efter en hollandsk videnskabsmand, der oprindeligt anvendte den til forfining af atompositioner i krystalstrukturanalyser. Metoden er endnu ikke en ren rutinemetode, men erfarne brugere kan opnå resultatet, der ikke eller kun vanskeligt kan opnås med andre metoder.

Metoden bygger på følgende grundlag:
For en ren fase er intensiteten, I, af en pulverlinje, der er målt ved hjælp af et røntgendiffraktometer givet ved nedenstående udtryk, hvor:

$\mathbf{K}$ : er en proportionalitetsfaktor

$\lambda$ : røntgenstrålens bølgelængde

e: elektronens ladning

r: diffraktometrets radius

$\mathbf{m}_{\mathrm{e}}$ : elektronens masse

c: lysets hastighed

n: multipliciteten for pulverlinjen

V: enhedscellens volumen

hkl: Miller-indices for pulverlinjen

$\mathbf{F}(\mathbf{h k l})$ : Strukturfaktoren for linjen

$\boldsymbol{\theta}$ : Bragg-vinklen

$\boldsymbol{\theta}_{\mathrm{m}}$ : monokromatorkrystallens refleksionsvinkel

$\mathbf{F}(\mathbf{h k l})=$

$\Sigma f_{j} \exp \left[2 \pi i\left(h_{x_{j}}+\mathrm{ky}_{\mathrm{j}}+\mathrm{lz}_{\mathrm{j}}\right)\right] \exp \left[-\mathrm{B}_{\mathrm{j}} \sin ^{2} \theta / \lambda^{2}\right]$

$\mathbf{f}_{\mathrm{j}}$ : atomspredningsfaktoren for atom $\mathrm{j}$

$\mathbf{x}_{\mathrm{i}}, \mathbf{y}_{\mathrm{i}}, \mathbf{z}_{\mathrm{i}}$ : koordinater for atom $\mathrm{j}$

B $_{\mathrm{i}}$ : Debye-Waller faktor (svingningsfaktor) for atom $\mathrm{j}$

$\mathbf{W}_{a}$ : vægtbrøken for fasen $\alpha$

$\boldsymbol{\rho}_{a}$ : massefylden for fasen $\alpha$

$\boldsymbol{\mu}_{\mathrm{M}}:$ massefylden for hele prøven

$$
\mathrm{I}=\mathrm{K} \frac{\lambda^{2} \mathrm{e}^{4}}{32 \pi \mathrm{rm}_{\mathrm{e}}^{2} \mathrm{c}^{4}} \frac{\mathrm{n}}{2 \mathrm{~V}^{2}} \cdot|\mathrm{F}(\mathrm{hkl})|^{2} \frac{1+\cos ^{2} \theta \cos ^{2} 2 \theta_{\mathrm{m}}}{\sin ^{2} \theta \sin \theta} \frac{\mathrm{W}_{\alpha}}{\rho_{\alpha} \mu_{\mathrm{M}}^{-}}
$$

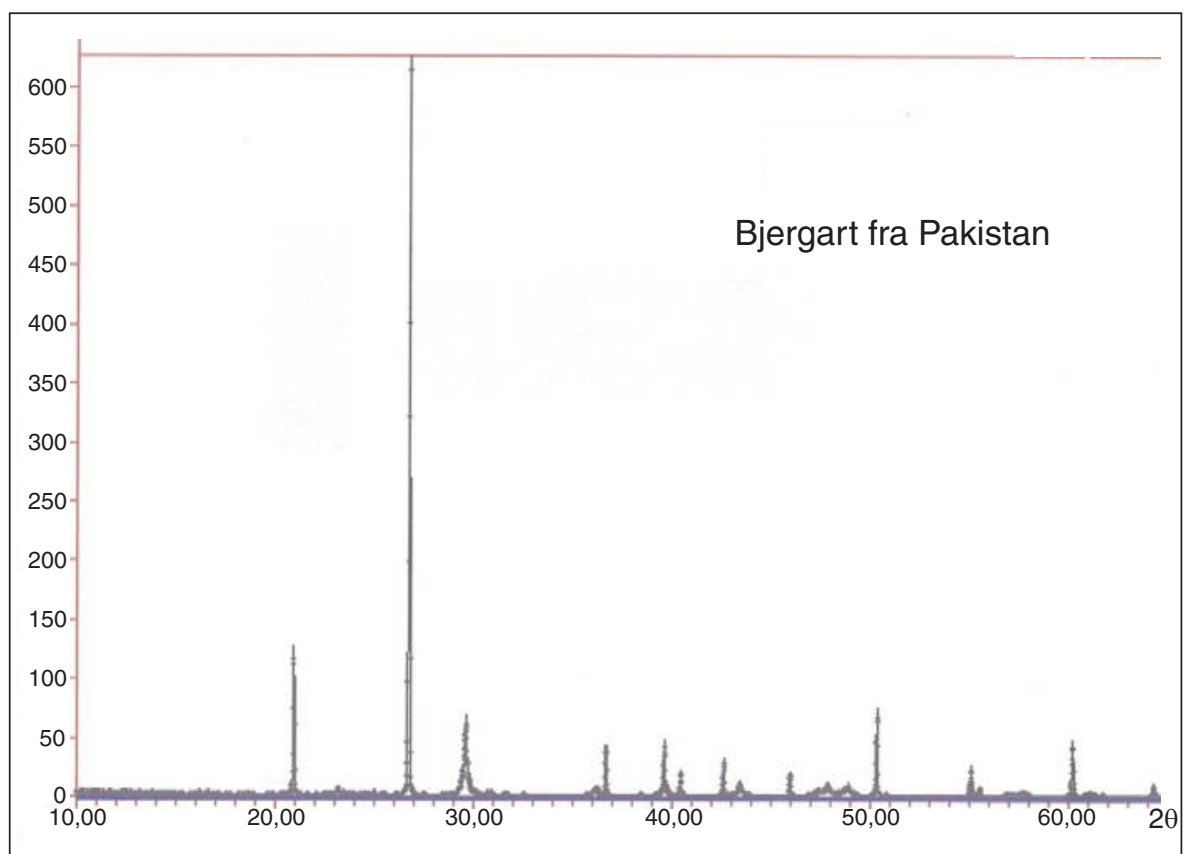

Pulverdiagram optaget med et moderne diffraktometer. (Grafik: UVH modificeret efter forfatterens forlag) 
For en given kemisk forbindelse, $\mathrm{fx}$ et mineral, er Bragg-vinklerne, $\theta_{i}$, for mineralets pulverdiagram uafhængige af tilstedeværelsen af andre mineraler. Intensitetsforholdene påvirkes imidlertid af tilstedeværelsen af andre faser.

Ligning (1) ser måske lidt overvældende ud, men de fleste størrelser er kendte eller kan let beregnes.

Rietveld-metoden bygger på, at samtlige faser $i$ en blanding er identificeret, og at

krystalstrukturerne af samtlige faser er kendte. For en tilfældig vinkel $2 \theta_{i} i$ et diffraktogram vil bidragene til intensiteten, $\mathrm{I}\left(2 \theta_{i}\right)$, for en enkelt fase, $\alpha, i$ almindelighed komme fra flere mere eller mindre overlappende Bragg-reflekser samt fra en baggrund. Udtrykket kan generelt formuleres således:

$\mathrm{I}\left(2 \theta_{\mathrm{i}}\right)=\mathrm{S}(\alpha) \Sigma_{\text {hkl }}\left[\mathrm{L}\left(2 \theta_{\mathrm{i}}\right) \cdot|\mathrm{F}(\mathrm{hkl})|^{2} \cdot \varphi\left(2 \theta_{\mathrm{i}}-2 \theta(\mathrm{hkl})\right]+\mathrm{b}\left(2 \theta_{\mathrm{i}}\right)(\mathbf{2})\right.$

hvor:

$\mathbf{S}(\boldsymbol{\alpha})$ : er en skalafaktor

$\mathbf{L}\left(\mathbf{2 \theta}_{\mathbf{i}}\right)$ : en geometrisk faktor, jvf. ligning (1)

$\mathbf{F}(\mathbf{h k l})$ : er en strukturfaktor, jvf. ligning (1)

$\varphi$ : er en funktion, der beskriver en refleksionsprofil, der er centreret omkring $2 \theta_{\text {hkl }}$, maksimum-vinklen for refleksen hkl

$\mathbf{b}\left(\mathbf{2 0}_{\mathrm{i}}\right)$ : er en baggrundsintensitet.

I beregningen af $F(h k l)$ indgår enhedscelleparametrene, a, b, c, $\alpha, \beta, \gamma$, samt strukturparametrene og Debye-Waller-faktoren. I beregningen af $\varphi$ indgår typisk seks til tolv parametre. Ved en mindste kvadraters analyse tilpasses beregnede $\mathrm{I}\left(2 \theta_{\mathrm{i}}\right)$ værdier til observerede. Generelt forfines skalafaktoren, enhedscelleparametrene og profilparametrene samt en baggrundsfunktion. For en enkelt, ren fase kan endvidere de strukturelle parametre, $x_{j}, y_{j}, z_{i}$, forfines. For en blanding må man normalt indskrænke sig til

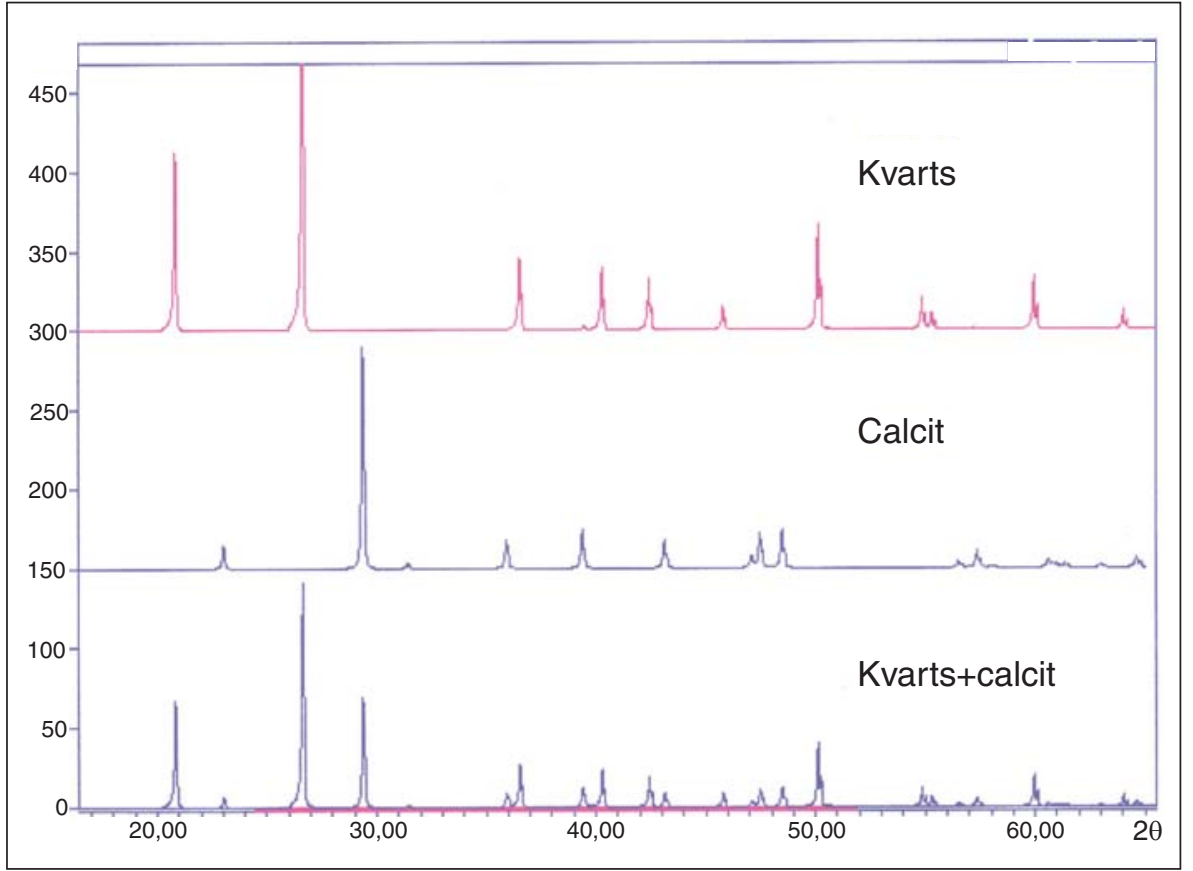

Eksemplet viser, at linjerne for et tofasesystem er summen af linjerne fra de to enkelte faser. Dette er grundlaget for anvendelsen af pulverdiffraktion til både kvalitativ og kvantitativ faseanalyse. (Grafik: UVH modificeret efter forfatterens forlceg)

at forfine hver fases skalafaktor, enhedscelleparametre, profilparametre og en fælles baggrundsfunktion. Bemærk, at i ligning (1) indgår størrelsen

$$
\frac{\mathrm{W}_{\alpha}}{\rho_{\alpha} \mu_{\mathrm{M}}^{-}}
$$

i skalafaktorerne, der således indeholder oplysning om prøvens kvantitative sammensætning. Forholdene mellem skalafaktorerne for de enkelte faser kan derfor omregnes til et sæt af vægtbrøker for faserne.

Der findes en række effektive "Public Domains", dvs. gratis programmer til Rietveld-metoden, der kan fås via Internettet. Anvendelsen af dem kræver en betydelig computerkapacitet, dog ikke mere end hvad der i dag normalt findes i en personlig computer, men hvad, der er mere vigtigt, forudsætter en korrekt anvendelse af metoden en del indsigt i krystallografi og den teoretiske baggrund for diffraktionsprocesserne. I reference 4) beskrives resultaterne fra en undersøgelse, hvor seks ens prøver blev analyseret i en række forskellige laboratorier. Det viste sig, at der var en ret stor spredning $i$ analyseresultaterne, omend flertallet gav acceptable resultater. Væsentlige unøjagtigheder fandtes især med prøver, der indeholdt stoffer med ekstrem ydre form såsom nåle- eller pladeform, hvorved der forekom en foretrukken orientering af krystallitterne. Store forskelle i absorptionskoefficienter mellem forskellige faser kan også give væsentlige fejl, medmindre der korrigeres for denne effekt, hvad de færreste programmer gør. Man gør derfor klogt i ikke at antage, at enhver Rietveld-analyse giver ufejlbarlige resultater.

\section{Data fra Geologisk Institut, Aarhus}

I foråret 2007 blev der på Geologisk Institut ved Aarhus Universitet anskaffet et røntgenpulverdiffraktometer af højeste kvalitet. I den forbindelse ønskede lektor Ole Bjørslev Nielsen at efterprøve apparatet ved at vurdere nye data af kendte standardmineraler og af blandinger deraf. Anne Thoisen og Charlotte Rasmussen optog med stor omhu diagrammer af 10 standard-mineraler (kaldet "monomineraler" der burde bestå af én enkelt fase) samt en lerprøve kaldet L4, der ikke vil blive omtalt nærmere her, da studiet af lermineraler er en videnskab i sig selv. Endvidere blev der lavet en række blandinger af standardprøverne. "Monomineralerne" var følgende:

Anhydrit, $\mathrm{CaSO}_{4}$, aragonit, $\mathrm{CaCO}_{3}$, baryt, $\mathrm{BaSO}_{4}$, calcit, $\mathrm{CaCO}_{3}$, dolomit, $\mathrm{CaCO}_{3}, \mathrm{MgCO}_{3}$, gips, $\mathrm{CaSO}_{4}, 5 \mathrm{H}_{2} \mathrm{O}$, kvarts, $\mathrm{SiO}_{2}$, magnesit, $\mathrm{MgCO}_{3}$, mikroklin, KAl$\mathrm{Si}_{3} \mathrm{O}_{8}$ og plagioklas, som specificeres senere samt salt, $\mathrm{NaCl}$.

Blandingerne omfattede blandt andre 9 kombinationer, $\{\mathrm{A}, \mathrm{B}\}$, hvor der for hver kombination blev lavet tre blandingsforhold: $\mathrm{A}_{\mathrm{x}}, \mathrm{B}_{1-\mathrm{x}}$ hvor $\mathrm{x}$ var henholdsvis 0,25 , 0,50 og 0,75 , altså 27 blandinger. De udvalgte standardprøver var: aragonit, calcit, dolomit, gips, kvarts og L4. Imidlertid blev ikke alle kombinationer af disse stoffer fremstillet. Endvidere blev der lavet blandinger med $99 \%$ kvarts og $1 \%$ calcit samt af $99 \%$ calcit og $1 \%$ kvarts. Ovennævnte diagrammer blev overladt til mig med henblik på en analyse efter Rietveld-metoden. Analysen viste, at anhydrit, aragonit, baryt, calcit, gips, kvarts, plagioklas og salt inden for måleusikkerheden var énfasesystemer. 
Programmet GSAS (General Structure

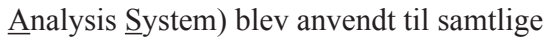
analyser.

\section{Rietveld-analyser på "monomineraler"} Kvarts

Da kvarts ofte anvendes som en sekundær standard i pulverdiffraktometri, var en detaljeret sammenligning med de data, der angives i PDF-databasen, af særlig interesse. De i PDF-basen angivne værdier er for en énkrystal af kvarts, der blev knust til pulver.

Nogle vigtige sammenligninger vises i tabellen nedenfor til venstre. De i parentes anførte tal for gitterkonstanterne a og c for PDF-data er sandsynligvis $2 \sigma$-værdier. Det ses, at differensen mellem $\mathrm{a}_{\mathrm{PDF}}$ og $\mathrm{a}_{\text {Rietveld }}$ er $0,0002 \AA$, og differensen mellem $\mathrm{c}_{\mathrm{PDF}}$ og $\mathrm{c}_{\text {Rietveld }}$ er $0,0003 \AA$, altså ca. $2 \sigma$. I statistikersprog ville man sige, at man har mindre end $5 \%$ sandsynlighed for at begå en fejl, hvis man forkaster den nulhypotese, at Århus-data og PDF-data hidrører fra forskellige typer materiale. Man kan således konkludere, at Århus-diffraktometret giver data, der er i god overensstemmelse med internationalt anerkendte værdier. I figuren øverst på denne side vises i grafisk form resultatet af Rietveld-analysen af kvarts:

For de øvrige énfasesystemer er konklusionerne lidt anderledes. Afvigelserne imellem data fra Århus og fra PDF er ganske vist så små, at identifikationen ikke kan drages i tvivl, men i nogle tilfælde er der evidens for, at der er små forskelle i kemisk sammensætning mellem prøverne fra Århus og dem fra PDF. For eksempel tyder resultaterne for baryt, $\mathrm{BaSO}_{4}$, fra Århus på, at

Gitterkonstanter for kvarts fra Rietveld-analyse i Ångström-værdier:

\begin{tabular}{|l|c|c|c|}
\hline & a & c & Volumen \\
\hline Resultat & 4,913527 & 5,405051 & 113,010 \\
\hline Sigma, $\sigma$ & 0,000016 & 0,000032 & 0,001 \\
\hline PDF-data & $4,9133(2)$ & $5,4053(4)$ & 113,00 \\
\hline
\end{tabular}

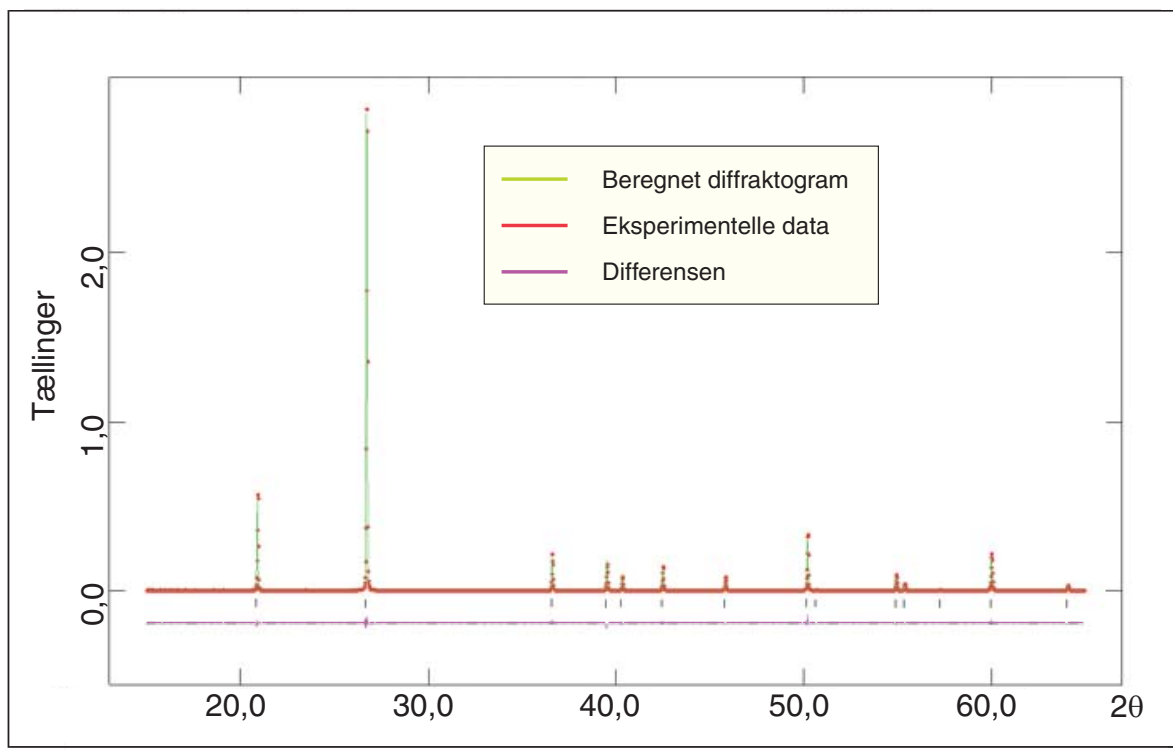

Den røde farve viser de eksperimentelle data, den grønne kurve det beregnede diffraktogram, og den violette kurve nederst $i$ billedet viser differensen mellem observerede og beregnede voerdier. (Grafik: UVH modificeret efter forfatterens forloeg)

$2-3 \%$ af bariumatomerne i prøven er erstattet af strontiumatomer. For salt, $\mathrm{NaCl}$, gælder det, at Århus-prøven kan indeholde små mængder af kalium og/eller brom.

For plagioklas, der defineres som en fast opløsning af albit, $\mathrm{NaAlSi}_{3} \mathrm{O}_{8}$, og anorthit, $\mathrm{CaAl}_{2} \mathrm{Si}_{2} \mathrm{O}_{8}$, angives sammensætningen ofte ved formlen $\mathrm{Ab}_{\mathrm{x}} \mathrm{An}_{1-\mathrm{x}}$. Mineralet andesin, der i PDF-filen er anført med sammensætningen: $0,62 \mathrm{NaAlSi}_{3} \mathrm{O}_{8}, 0,38 \mathrm{CaAl}_{2} \mathrm{Si}_{2} \mathrm{O}_{8}$, forkortet som $\mathrm{Ab}{ }_{62} \mathrm{An}_{38}$, viste god overensstemmelse med data for Århus-prøven. Den struktur, der blev udgangspunkt for forfinin- gen, beskrives imidlertid som $\mathrm{Ab}_{.52} \mathrm{An}_{.48}$, et mineral fra Hogarth Ranges, Australien. Strukturdata fra dette mineral kunne forklare $2 \theta$-værdierne for alle linjerne, men det blev nødvendigt også at forfine på strukturkoordinaterne for at få en tilfredsstillende overensstemmelse med intensiteterne, men der blev ikke ændret på den kemiske sammensætning. Gitterkonstanterne vises i tabellen nedenfor til højre:

De relative afvigelser mellem cellelængderne fra PDF-værdierne og dem fra Rietveld-forfiningen er som følger: $\Delta \mathrm{a} / \mathrm{a}=0,06$

Gitterkonstanter for en plagioklas - Århus-data:

\begin{tabular}{|l|c|c|c|c|c|c|c|}
\hline & $\mathrm{a}$ & $\mathrm{b}$ & $\mathrm{c}$ & alpha & beta & gamma & Volumen \\
\hline Resultat & 8,168488 & 12,858317 & 7,109797 & 93,561 & 116,249 & 89,895 & 668,192 \\
\hline Sigmas, $\sigma$ & 0,000149 & 0,000195 & 0,000086 & 0,002 & 0,001 & 0,002 & 0,018 \\
\hline PDF-data & 8,164 & 12,857 & 7,118 & 93,69 & 116,3 & 89,59 & 668,22 \\
\hline
\end{tabular}




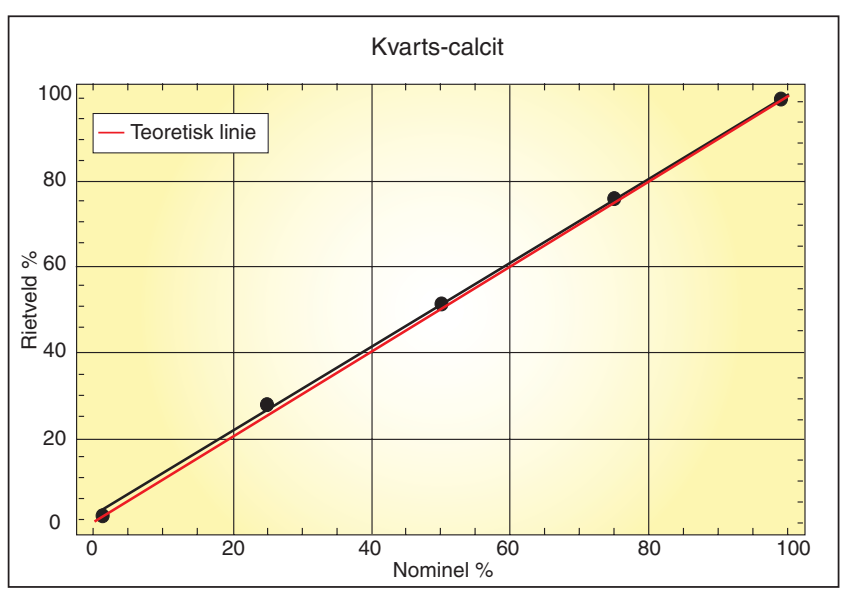

Kvartsindholdet bestemmes generelt lidt for højt hér. (Grafik: UVH modificeret efter forfatterens forloeg)

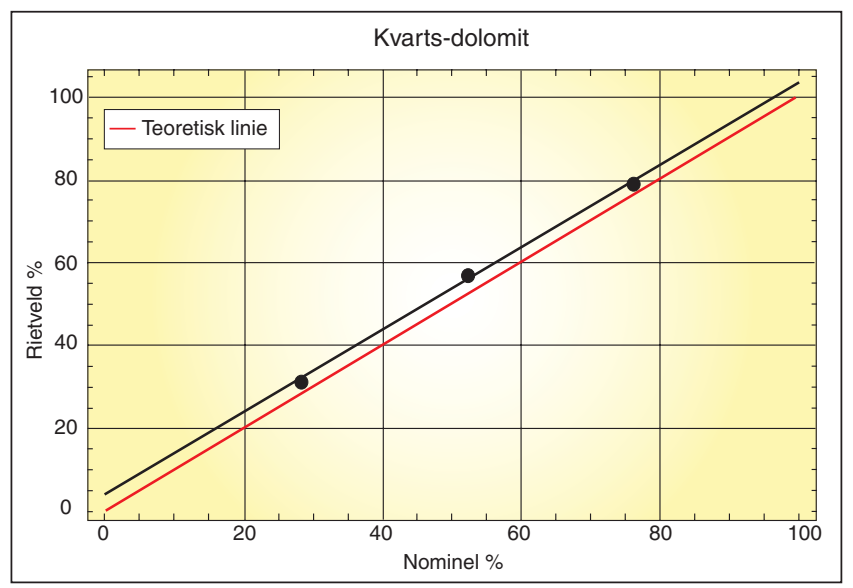

Alle kvartsvardier bestemt ved Rietveld-metoden er for høje. (Grafik: UVH modificeret efter forfatterens forlog)

\section{B: Kvarts - Calcit}

For kvarts-calcit-blandingerne er billedet lidt anderledes. Her har vi både nominelle og Rietveld-værdier nær skalaens endepunkter. For blandingen med nominelt $99 \%$ kvarts findes $98,91 \%$, hvilket må siges at være tilfredsstillende. Ligeledes for blandingen med $1 \%$ kvarts, hvor der findes 1,6\%, hvilket er acceptabelt for så små mængder. Regressionslinjens hældningskoefficient er 0,986. Kvartsindholdet her bestemmes generelt lidt for højt, se figuren øverst til venstre på denne side

I disse beregninger regnes der med, at calcit viser foretrukken orientering efter 104.

\section{C: Kvarts - Dolomit}

Som tidligere omtalt kompliceres kvarts-dolomit-blandingernes forhold af, at dolomitstandarden indeholder $4,3 \%$ kvarts, og at dolomitten synes at bestå af to lidt forskellige dolomit-faser, hvoraf den ene kaldes "dolomit med Fe".

Lineariteten mellem nominelt og Rietveld-bestemt kvartsindhold er god. Regressionsliniens hældningskoefficient er 0,993, men som det ses på grafen øverst til højre på denne side, er alle kvartsværdier bestemt ved Rietveld-metoden for høje.

\section{D: Kvarts - Gips}

For kvarts-gips-blandingerne er forholdene anderledes. Her ses kvartsindholdet at være væsentligt lavere end det nominelle. Som det ses på figuren nedenfor, er sammenhængen mellem de nominelle kvartsprocenter og dem, der er fundet ved Rietveld-metoden, nogenlunde lineær, men kurven ligger langt under den teoretiske værdi, og der er her ikke parallelitet mellem den observerede og den teoretiske linje. I beregningerne indgår der en antagelse af, at gips viser foretrukken orientering efter 010 .

\section{Konklusion}

Disse fire eksempler viser, at man for binære blandinger kan få en god lineær sammenhæng mellem nominelle værdier og værdier fra Rietveld-forfininger. I nogle tilfælde får man også relativt nøjagtige bestemmelser. Der er publikationer, der beretter om meget præcise bestemmelser af flerfasesystemer. Præcisionen afhænger blandt andet af, hvor god prøvetilberedningen og tællestatistikken er. Det bør endvidere bemærkes, at den præcision, hvormed indholdet af en fase kan bestemmes, aftager med antallet af faser $i$ prøven.

Flere af de her anførte eksempler viser imidlertid, at man ikke uden videre kan regne med, at man ved Rietveld-metoden altid får korrekte resultater. Især ikke når én eller flere komponenter udviser foretrukken orientering som fx ved gips. Om end formålet her har været at beskrive en standardfri metode, bør det dog nævnes, at man kan forøge sikkerheden $\mathrm{i}$ analysen ved at tilføje en standardsubstans i kendt mængde. Tilsætning af en standard er en

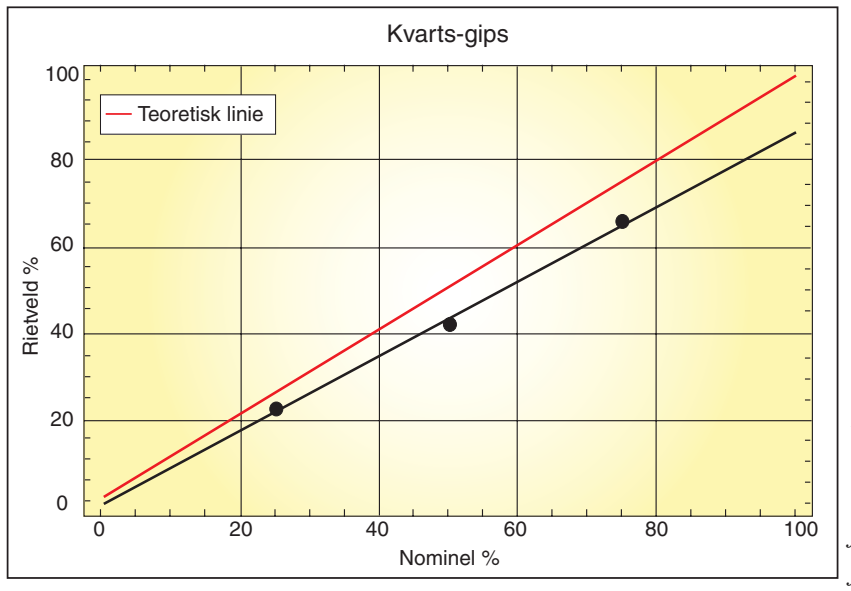

Kvartsindholdet ses hér at vore voesentligt lavere end det nominelle. (Grafik: UVH modificeret efter forfatterens forlog) 
nødvendighed, hvis man ønsker at kvantificere mængden af en amorf fase. Endvidere er det værd at nævne, at et ofte overset aspekt ved Rietveld-metoden er den ekstra sikkerhed, man opnår for den kvalitative analyse, når man også kvantitativt kan gøre rede for tilstedeværelsen af hver enkel fase $i$ et multifasesystem.

Forfatteren takker Ole Bjørslev Nielsen, Charlotte Rasmussen og Anne Thoisen for godt samarbejde og for fri adgang til indsamlede data. Endvidere takker han Ulla V. Hjuler og Charlotte Rasmussen for hjoelp til forbedring af prosentationen af billedmaterialet.

\section{Referencer:}

1) Rietveld, H. M. (1967). "Line Profiles of Neutron Powder-Diffraction Peaks for Structure Refinement", Acta Cryst., Vol. 22, 151- 152.

2) Rietveld, H. M. (1969). "A Profile Refinement Metod for Nuclear and Magnetic

\section{Kort nyt}

\section{Kondomer som klimahjælper}

Den britiske tænketank Optimum Population Trust (OPT) har beregnet, at $33 \mathrm{kr}$. brugt på kondomer og p-piller i ulandene kan reducere $\mathrm{CO}_{2}$-udslippet med et ton, hvilket gør det til et langt billigere klimaindsatsområde end at investere i fx sol- og vindenergi. Ifølge tænketanken får man langt mere for pengene i form af $\mathrm{CO}_{2}$-reduktion, hvis i-landene investerer i familieplanlægning og gratis uddeling af præventionsmidler i udviklingslandene, end hvis tilsvarende beløb var blevet anvendt på alternative energikilder.

Ifølge OPT vil det koste 1.088 mia. kr. at reducere befolkningstilvæksten med 500 mio. frem til 2050 svarende til en $\mathrm{CO}_{2}$-reduktion på 34 gigaton. Til sammenligning vil det koste næsten fem trillioner kr. at opnå samme reduktion gennem grønne teknologier.

Verdens befolkning vokser i øjeblikket med 84 mio. mennesker om året, og ifølge FN vil Jordens befolkning vokse fra 6,8 mia. i dag til ca. 9 mia. i 2050.

Miljøstrateg ved OPT, David Burton, opfordrede politikerne til at sætte befolk-
Structures", J. Appl. Cryst., Vol. 2, 65- 71. 3) Larson, A. C. and Von Dreele, R. B. (2001). General Structure Analysis System ( GSAS ), Los Alamos National Laboratory Report LAUR 86-748.

4) Scarlett, N. V. Y., Madsen, I. C.,

Cranswick, L. M. D., Lwin, T., Groleau, G., Stephenson, G., Aylmore, M. and Agron-Olshina, N. (2002). "Outcomes of the International Union of Crystallography Commission on Powder Diffraction Round Robin on Quantitative Phase Analysis: samples 2, 3 , 4, synthetic bauxite, natural granodiorite and pharmaceuticals", J. Appl. Cryst.

Gipskrystal. Den ydre form af krystaller bevares normalt ved pulverisering. Derfor vil små gipskrystaller fortrinsvis laegge sig på den store, flade side i prøver til pulverdiffraktion. Det kaldes "foretrukken orientering”. (Foto: Ole Johnsen, Geologisk Museum) Vol.35, 383-400.

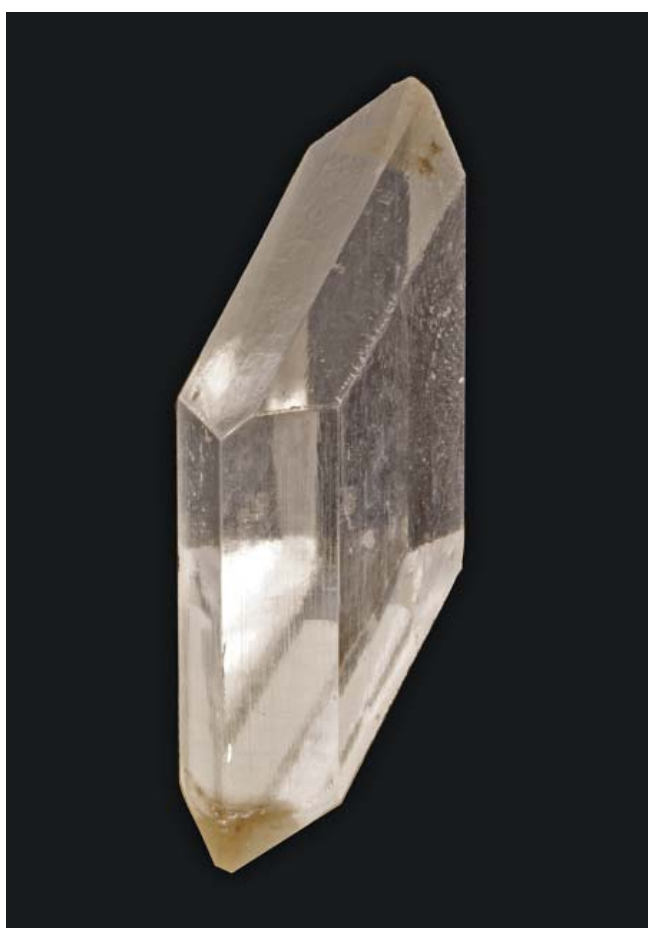

ningstilvæksten på dagsordenen ved klimatopmødet i København, idet $\mathrm{CO}_{2}$-udslippets størrelse i stor udstrækning afhænger af Verdens befolknings størrelse.

David Burton fremhæver Iran som et godt eksempel trods det despotiske og brutale muslimske teokrati, der styrer landet. På ti år har man stoppet befolkningstilvæksten i Iran ved at undervise nygifte par, således at gennemsnittet $\mathrm{i}$ dag er to fødte børn pr. kvinde.

OPT, som bl.a. støttes af profiler som David Attenborough, der i mange år stod bag legendariske naturudsendelser på $\mathrm{BBC}$, opfordrer via dets hjemmeside www.popoffsets.com enkeltpersoner og virksomheder til at beregne deres $\mathrm{CO}_{2}$-aftryk og donere penge til prævention og familieplanlægning i ulandene.

\section{$J P / S L J$}

\section{Enge og moser forsvinder}

Enge bliver i stigende grad pløjet op, og flere og flere moser bliver fyldt op med jord af landmænd, som ikke overholder naturfredningslovgivningen. Danmarks Na- turfredningsforening er på vej med omkring 250 sager om ødelagt natur alene i FaaborgMidtfyn kommune.

Foreningens direktør René la Cour Sell er af den opfattelse, at der i stort set hver eneste kommune i Danmark kan føres sager, hvor landmænd har overtrådt naturfredningsbestemmelserne.

Ved at sammenligne gamle luftfotos med nyere overblikskort er det lykkedes foreningen at finde sagerne om overtrædelse af naturbeskyttelsesloven i Faaborg-Midtfyn kommune.

Ritzau/SLJ

\section{Jordskælv i Argentina}

Et jordskælv målt til 6,1 på Richter-skalaen rystede 16. november det nordlige Argentina nær grænsen til Chile og Bolivia ifølge USA's Geologiske Overvågning (USGS).

Skælvet ramte dele af Andesbjergene omkring $190 \mathrm{~km}$ nordvest for San Salvador de Jujuy. Der var ikke umiddelbart meldinger om hverken ødelæggelser eller tilskadekomne.

AFP/SLJ 